\title{
Timeliness Value and Free-from-error Quality of Accounting Information: A Study on Commercial Banks
}

\author{
Mohammad Jafaur Ahamed \\ Associate Professor (Accounting), Open School, Bangladesh Open University, Gazipur, BANGLADESH \\ E-mail for correspondence: jafaur@yahoo.com
}

https://doi.org/10.18034/abr.v10i2.479

\begin{abstract}
This paper makes an effort to assess the timeliness value and free-from-error quality of accounting information generated by AIS through the avenue of annual reports of the selected commercial banks in Bangladesh. An opinion survey was run through a closed questionnaire- designed by using a fivepoint Likert scale. Based on primary data, the study reveals that the qualities of accounting information produced by AIS of commercial banks are satisfactory in terms of both timeliness and free-from-error, yet inadequate in absolute terms. Moreover, the study substantiates that there is no significant variation (homogeneity) of opinion among the respondents regarding the timeliness and accuracy of accounting information. The outcomes of the study identified that the feature of annual reports of commercial banks in Bangladesh is not up to the standard due to erratic power supply, poor communication infrastructures, the accidental entry of poor data, virus infection, unauthorized accessing, copying, printing and distributing of data or information, etc. Consequently, respective authorities are highly encouraged to come forward to ensure the maximum qualities of AIS. The study has focused on two qualitative characteristics and only on the annual report. Thus, further research is recommended to conduct focusing on others such as quarterly and interim reports, bank circulars, financial press releases, etc. to investigate the extent of additional qualities, for instance, feedback value, credible value, clarity value, etc.
\end{abstract}

Key words: Qualitative characteristics, Accounting information, AIS, Timeliness value, Free-from-error quality

\section{INTRODUCTION}

Banking Company is a financial institution that performs the functions of receiving deposits from the people and giving loans for investment with the target of earning profit. The general role of banks is to provide financial services to general people and businesses ensure economic and social stability and sustainable development of the economy. In this respect, credit creation is the most significant function of commercial banks. There are six state-owned commercial banks, three development financial institutions, forty-one private commercial banks, and nine foreign commercial banks operating in Bangladesh (Source: Bangladesh Bank's Annual Report 201819). Operating a business under competitive pressures induced by globalization and digitalization, all these banks understand that rigid and disqualified business information system is not appropriate for critical business process and effective decision-making. In addition, competitive pressures have recommended innovative methodologies and techniques like Enterprise Information System, Point of Scale System, Accounting Information System, Marketing Information System, Management Information System, and Executive Information System, etc. Among these methodologies and techniques, qualitative AIS is highly recommended by many scholars to run banks truly and fairly in a cutthroat and technological environment. A qualitative accounting information system means accounting information supplied to the stakeholders should have some specific characteristics that to be useful for decision-making. According to Kieso and Weygandt (2011), qualitative characteristics of accounting information include relevance, reliability, comparability, and consistency. According to Bushman and Smith (2004), transparency of corporate reporting depends principally on qualitative financial accounting disclosures, governance disclosure, timeliness, and credibility of disclosures and accounting policies. The 
Financial Accounting Standards Board has prescribed some essential qualitative characteristics of accounting information produced by AIS that distinguish information from inferior information for decision-making purposes. Timelines value and free-from-error quality are the two primary qualities that make accounting information useful to the stakeholders for decision-making purposes. Timeliness is an important quality of corporate financial reporting. The information must bear timeliness to treat as relevant. Accounting information is capable of affecting a decision if it is available at the time of decision-making. To be useful/effective AIS should be accurate and fast while processing financial information. Moreover, it should provide management with essential information within a reasonable period. Similarly, an information item that is free-from-error will be a more accurate (faithful) representation of a financial item. AIS produces financial accounting data to external stockholders, investors, lenders, governmental agencies, and internal users. This data must be certifiably free of the specific types of errors since a firm is subject to data quality control assessment conducted by auditors at any time during operations (Kaplan et al., 1998). Free from error quality makes an annual report of commercial banks trustworthy or reliable to its stakeholders. Information of an entity is considered as accurate when the entity reflects all of its data in its records. The more accurate the information is, the higher the quality, and the more securely stakeholders can rely on it in making decisions (Stoner et al. 1995). Inaccurate and incomplete data may adversely affect the competitive success of an organization (Redman, 1992). Indeed, poor quality information can have significant social and business impacts.

\section{NeEd for the Study}

Qualitative accounting information has pivotal importance for a vast number of stakeholders, as it affects the quality of decision-making. Providing qualitative accounting information is a prerequisite for the success of the business. Qualitative accounting information characterized by its completeness, accuracy, timeliness, understandability, security, reliability, comparability, verifiability, free-fromerroneous, etc. These qualitative characteristics of AIS based on some regulatory frameworks in banking sectors bear a significant impact on banks' specific characteristics, managerial performance, growth, and developments. The banking business has some distinctive features such as it produces and sells financial services instead of products; it is a highly leveraged firm, it acts as a connecting link between borrowers and lenders, and it deals only with money. These specific features compel the banks to provide free-from-error information to the stakeholders in time. If a bank fails to provide correct information timely, it gets into trouble, and consequently, the entire economy and community are affected adversely. Measurement and assessment of the quality and effectiveness of accounting information are particularly important, as these activities will increase both the quality of economic decision-making for users and the overall market efficiency of the business (Nicolaou, 2000). Thus, the study would contribute to assessing the qualitative characteristics of accounting information produced by the AIS of commercial banks in Bangladesh. Although many research studies were done on commercial banks in Bangladesh, as of now, few studies have done on timeliness value, and the free-from-error quality of accounting information of commercial banks even remains unexplored until now. These are the driving forces to choose this topic as a research study, and hope that it would be helpful for concerned policy-makers, researchers, economic planners, government, and other interested parties.

\section{REVIEW OF RELATED LiteratuRE}

Several most studies related to the timeliness value and free-from-error quality of accounting information were reviewed here, focusing on their findings. A study entitled "Qualitative characteristics of financial reporting: An evaluation of users' perception in Bangladesh." conducted by Hasan et al. (2014) found that the users' perception of the timeliness value of corporate financial reporting is far below the admissible level, and, as such users hold negative perceptions towards the financial disclosures. Researchers also found that there exists a significant variation among the respondents' perceptions regarding the timeliness value of accounting information. Bukenya (2014) performed a study to make a relationship between the quality of accounting information and the financial performance of the public sector in Uganda. The author mentioned that accuracy and timeliness are standard measures of the quality of accounting information through factor analysis. The author also found that there is a significant positive relationship with approximately $58 \%$ of the financial performance levels attributed to financial information quality. Salehi and Rostami (2011) operated a study focused on the qualitative characteristics arrangement in the special condition in Iran, to determine the weight and importance of each component of qualitative characteristics upon the perception of the three main engaged groups namely professional members, users, and preparers of accounting information in financial reporting. Respondents among seven investigated qualities were less satisfied due to inadequate disclosure, insufficient consideration of cost-benefit, and lack of sufficient reliability of the information. On the other hand, respondents were also relatively satisfied with the qualities of comparable, timeliness, and conservative manner. Obaidat (2007) found a gap between the opinions of external auditors and the investors in terms of qualitative characteristics of accounting information that attributed to the disagreement among them about qualitative features like relevance, timeliness, and predictive value. Sumon \& Shilpi (2008) mentioned in their study that an effective accounting information system is essential to any organization's long-run success. Researchers provided some suggestions, if financial institutions apply real-time 
processing or on-line processing for their operation, they will be able to enjoy some competitive advantage because realtime data processing is more accurate than batch processing, and any errors can be easily corrected. Real-time processing ensures that stored information is always current, thereby increasing its usefulness for making decisions. Abdelkarim et al. (2009) found an unfavorable perception, along with poor credibility and slowness of the disclosures, that creates an adverse effect on stock prices in the Palestine Securities Exchange. Naser et al. (2003) provided a study on the perceptions of various users of financial information in Kuwait. The respondents of the study opined that trustworthiness, credibility, and timeliness as the critical characteristics of useful corporate information. The respondents also confirmed that the regular/on time published and reliable annual report does play an important role when making their investment decisions, evaluating the company's performance, and monitoring their investments. Neogy (2014) expressed in his study that adequate accounting information is essential for taking every effective decision-making process, and enough information is possible if the Accounting Information Systems run efficiently. The efficient Accounting Information Systems is necessary because it ensures that all levels of management get sufficient, adequate, relevant, and transparent information for planning and controlling activities of the business organization. Aljifri (2008) found that the information system is essential not only in the acquiring and processing of information but also in providing information on when they could be useful.

\section{Research Question}

The ultimate goal of this study to answer the question: what are views and perceptions the users of commercial banks' annual reports hold on the timeliness value and free-from-error quality of information produced by AIS prescribed by FASB?

\section{Objectives of the Study}

For the study, the following objectives have been identified:

- Assess and explain the respondents' perceptions of timeliness value and free-from-error quality of accounting information provided by the commercial banks in Bangladesh;

- Offer valuable suggestions for quality improvement of accounting information of commercial banks in Bangladesh.

\section{Hypotheses of the Study}

Based on the ultimate goal and objectives, the current study investigates the following two alternative hypotheses drawn on users' perceptions on the timeliness value and freefrom-error quality of accounting information:
$\mathrm{H}_{1}$ : There is a significant difference in the opinions of the user groups about the timeliness value of accounting information supplied by AIS of commercial banks in Bangladesh

$\mathrm{H}_{2}$ : There is a notable difference in the notions of the respondent groups about the accuracy of accounting information generated by AIS of commercial banks in Bangladesh

\section{Methodology OF the Study}

The present study was carried out mainly based on primary data, though few secondary data were considered as well. The primary data were collected through personal visits and interviews with respondents. For getting primary data, two hundred fifty closed questionnaires were delivered among the total number of respondents (250) - segmented into five categories: bank officials, professional accountants \& consultants, investors, respective other officials, and academicians (fifty questionnaires in each group). Among the total distributed questionnaires, two hundred fifteen were recouped, i.e., $86 \%$ of the total number of papers distributed. To maintain uniformity, two hundred five questionnaires (forty-one from each category) were endured to the statistical analysis, which covered $95.35 \%$ of the total response recovered. Before completing the questionnaire, deep concentration was paid to make sure that respondents did not face any ambiguity regarding questions related to AIS qualities. Timeliness value and free-from-error quality were explored through the opinions of respondents; alternative hypotheses were examined by the Pearson Chi-square test $\left(\chi^{2}\right)$. The data was critically examined with the help of different statistical tools like percentage, mode value, standard deviation, maximum value, minimum value, etc.

\section{Discussions AND FINDINGS}

Based on primary data and statistical analysis, the summaries of the findings of the study are:

Timeliness Value of Accounting Information: Timeliness is an essential quality of corporate financial reporting. To be relevant, information must bear timeliness quality. Accounting information is capable of affecting a decision if it is available at the time the decision-making. Although timeliness alone cannot make it relevant, information that is not published timely is irrelevant. Timeliness of accounting information is a crucial factor that can influence the decision-making process. But, it is found that the banking companies operating in Bangladesh do not maintain timeliness in disclosing their accounting information. In this respect, the users' response on the timeliness of accounting information and their opinions are presented in the following table- 
Table 1: Opinions of the Respondents Regarding the Timeliness Value of Accounting Information Produced by AIS of the Selected Commercial Banks

\begin{tabular}{|c|c|c|c|c|c|c|c|c|c|c|c|c|}
\hline \multirow[t]{2}{*}{ Scale } & \multirow{2}{*}{$\begin{array}{c}\text { N \& } \\
\%\end{array}$} & \multicolumn{5}{|c|}{ User Groups } & \multirow[t]{2}{*}{ Total } & \multirow[t]{2}{*}{ Mode } & \multirow[t]{2}{*}{ SD } & \multirow[t]{2}{*}{$\chi^{2}$} & \multirow[t]{2}{*}{ DF } & \multirow[t]{2}{*}{ SL. } \\
\hline & & ACAD & INV & BEX & ROO & PAAC & & & & & & \\
\hline \multirow{2}{*}{ Very late } & $\mathrm{N}$ & 1 & 2 & 0 & 0 & 0 & 3 & \multirow{12}{*}{4} & \multirow{12}{*}{.994} & \multirow{12}{*}{19.37} & \multirow{12}{*}{16} & \multirow{12}{*}{250} \\
\hline & $\%$ & $0.5 \%$ & $1.0 \%$ & $0.0 \%$ & $0.0 \%$ & $0.0 \%$ & $1.5 \%$ & & & & & \\
\hline \multirow{2}{*}{ late } & $\mathrm{N}$ & 6 & 13 & 7 & 11 & 9 & 46 & & & & & \\
\hline & $\%$ & $2.9 \%$ & $6.3 \%$ & $3.4 \%$ & $5.4 \%$ & $4.4 \%$ & $22.4 \%$ & & & & & \\
\hline \multirow{2}{*}{ Neutral } & $\mathrm{N}$ & 15 & 5 & 8 & 9 & 11 & 48 & & & & & \\
\hline & $\%$ & $7.3 \%$ & $2.4 \%$ & $3.9 \%$ & $4.4 \%$ & $5.4 \%$ & $23.4 \%$ & & & & & \\
\hline \multirow{2}{*}{ Rapidly } & $\mathrm{N}$ & 13 & 19 & 20 & 17 & 18 & 87 & & & & & \\
\hline & $\%$ & $6.3 \%$ & $9.3 \%$ & $9.8 \%$ & $8.3 \%$ & $8.8 \%$ & $42.4 \%$ & & & & & \\
\hline \multirow{2}{*}{ Very rapidly } & $\mathrm{N}$ & 6 & 2 & 6 & 4 & 3 & 21 & & & & & \\
\hline & $\%$ & $2.9 \%$ & $1.0 \%$ & $2.9 \%$ & $2.0 \%$ & $1.5 \%$ & $10.2 \%$ & & & & & \\
\hline \multirow{2}{*}{ Total } & $\mathrm{N}$ & 41 & 41 & 41 & 41 & 41 & 205 & & & & & \\
\hline & $\%$ & $20.0 \%$ & $20.0 \%$ & $20.0 \%$ & $20.0 \%$ & $20.0 \%$ & $100.0 \%$ & & & & & \\
\hline
\end{tabular}

Source: Self Constructed Table Based on Primary Data

Note: $\mathrm{ACAD}=$ Academicians; INV. = Investors; BEX. = Bank Executives; ROO = Respective Other Officials; PAAC = Professional Accountants and Consultants; $\mathrm{SD}=$ Standard Deviation, $\chi 2=$ Chi-square; DF $=$ Degree of Freedom; SL. = Significant Level; $\mathrm{N}=$ No. of Respondents

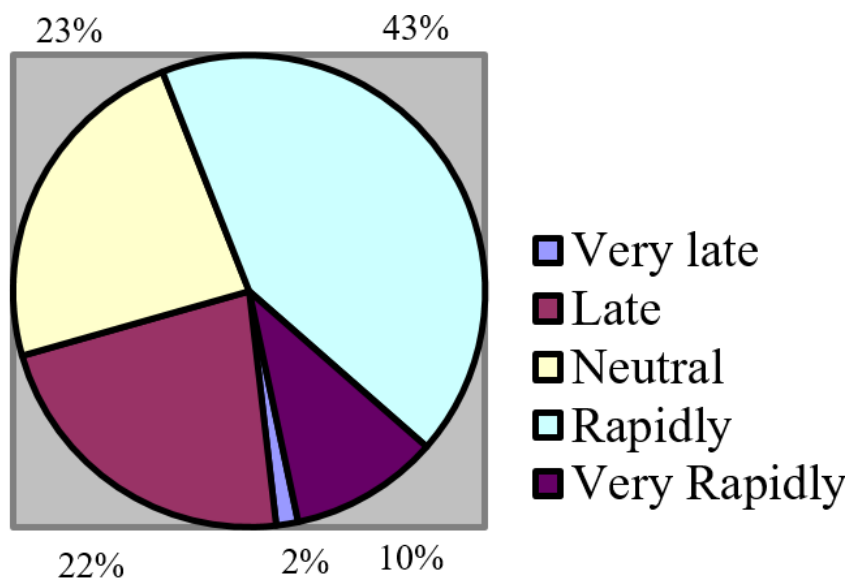

Figure 1: Opinions of the Respondents Regarding the Timeliness of Accounting Information

Table and figure 1 show that $42.4 \%$ of respondents believe that commercial banks rapidly produced information in annual reports; $10.2 \%$ of respondents think that information provided very rapidly. As against this, $22.4 \%$ of respondents perceive that commercial banks delayed in producing accounting information; $23.4 \%$ of respondents are in the neutral position in this regard; and, only $1.5 \%$ of respondents believe that it took a long time for institutions to produce information. Based on the opinion of the majority of the respondents, it is found that commercial banks in Bangladesh properly maintain the quality of financial reporting in terms of timeliness of accounting information. To see the existence of any significant difference among the opinions of the respondents regarding the timeliness of accounting information, produced by AIS of the selected commercial banks, the following alternative hypothesis is drawn:

$\mathrm{H}_{1}$ : There is a significant difference in the opinions of the user groups about the timeliness value of accounting information supplied by AIS of commercial banks in Bangladesh

To justify the presence of any significant variation between the opinions of the respondents regarding the timeliness of accounting information, produced by Accounting Information Systems of the selected commercial banks, Pearson Chi-square test $\left(\chi^{2}\right)$ using SPSS -22 was utilized. The value of Pearson Chi-square test $(\chi 2)$ is $19.37(\mathrm{~N}=205, \mathrm{DF}=16, \mathrm{SD}=.994$ and mode $=4)$ which is significant at .250 levels $(\mathrm{P}>0.1)$. Therefore, the alternative hypothesis is void, which means that there is no mentionable variation (homogeneity) of opinion among the respondents regarding the timeliness of accounting information supplied by Accounting Information Systems of the selected commercial banks in Bangladesh. The opinion survey result is consistent with Salehi and Rostami (2011), whereas inconsistent with Hasan et al. (2014), and Abdelkarim et al., (2009).

Free-from-error quality of Accounting Information: Free-from-error quality means that the information must not contain any material error, biases, and misleading data. Information that is free from error will be a more accurate (faithful) representation of a financial item. The following table reflects the picture of free-from-error of accounting information generated by the Accounting Information Systems of commercial banks in the viewpoint of respondents' opinion: 
Table 2: Opinions of the Respondents Regarding the Free-from-error Quality of Accounting Information Produced by AIS of the Selected Commercial Banks

\begin{tabular}{|c|c|c|c|c|c|c|c|c|c|c|c|c|}
\hline \multirow[t]{2}{*}{ Scale } & \multirow{2}{*}{$\begin{array}{c}\text { N \& } \\
\%\end{array}$} & \multicolumn{5}{|c|}{ User Groups } & \multirow[t]{2}{*}{ Total } & \multirow[t]{2}{*}{ Mode } & \multirow[t]{2}{*}{ SD } & \multirow[t]{2}{*}{$\chi^{2}$} & \multirow[t]{2}{*}{ DF } & \multirow[t]{2}{*}{ SL. } \\
\hline & & ACAD & INV & BEX & ROO & PAAC & & & & & & \\
\hline \multirow{2}{*}{$\begin{array}{l}\text { Not free from } \\
\text { error at all }\end{array}$} & $\mathrm{N}$ & 1 & 4 & 2 & 4 & 4 & 15 & \multirow{12}{*}{4} & \multirow{12}{*}{1.19} & \multirow{12}{*}{9.14} & \multirow{12}{*}{16} & \multirow{12}{*}{.907} \\
\hline & $\%$ & $0.5 \%$ & $2.0 \%$ & $1.0 \%$ & $2.0 \%$ & $2.0 \%$ & $7.3 \%$ & & & & & \\
\hline \multirow{2}{*}{$\begin{array}{l}\text { Partially free } \\
\text { from error }\end{array}$} & $\mathrm{N}$ & 4 & 9 & 10 & 8 & 10 & 41 & & & & & \\
\hline & $\%$ & $2.0 \%$ & $4.4 \%$ & $4.9 \%$ & $3.9 \%$ & $4.9 \%$ & $20.0 \%$ & & & & & \\
\hline \multirow{2}{*}{ Undecided } & $\mathrm{N}$ & 9 & 7 & 9 & 8 & 7 & 40 & & & & & \\
\hline & $\%$ & $4.4 \%$ & $3.4 \%$ & $4.4 \%$ & $3.9 \%$ & $3.4 \%$ & $19.5 \%$ & & & & & \\
\hline \multirow{2}{*}{ Free from error } & $\mathrm{N}$ & 18 & 15 & 14 & 12 & 12 & 71 & & & & & \\
\hline & $\%$ & $8.8 \%$ & $7.3 \%$ & $6.8 \%$ & $5.9 \%$ & $5.9 \%$ & $34.6 \%$ & & & & & \\
\hline \multirow{2}{*}{$\begin{array}{l}\text { Fully free from } \\
\text { error }\end{array}$} & $\mathrm{N}$ & 9 & 6 & 6 & 9 & 8 & 38 & & & & & \\
\hline & $\%$ & $4.4 \%$ & $2.9 \%$ & $2.9 \%$ & $4.4 \%$ & $3.9 \%$ & $18.5 \%$ & & & & & \\
\hline \multirow{2}{*}{ Total } & $\mathrm{N}$ & 41 & 41 & 41 & 41 & 41 & 205 & & & & & \\
\hline & $\%$ & $20.0 \%$ & $20.0 \%$ & $20.0 \%$ & $20.0 \%$ & $20.0 \%$ & $100.0 \%$ & & & & & \\
\hline
\end{tabular}

Source: Self Constructed Table Based on Primary Data

Note: $\mathrm{ACAD}=$ Academicians; INV. = Investors; BEX. = Bank Executives; ROO = Respective Other Officials; PAAC = Professional Accountants and Consultants; $\mathrm{SD}=$ Standard Deviation, $\chi 2=$ Chi-square; $\mathrm{DF}=$ Degree of Freedom; SL. $=$ Significant Level; $\mathrm{N}=$ No. of Respondents

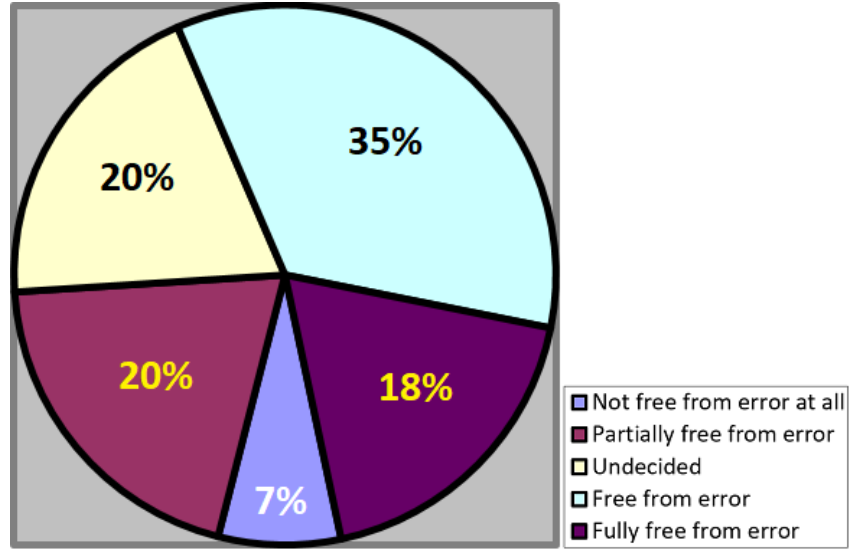

Figure 2: Opinions of the Respondents Regarding the Free-from-error Quality of Accounting Information

Table and figure 2 show that $34.6 \%$ of respondents perceive commercial banks produce information that is free-from-error in annual reports; $18.5 \%$ of respondents opined that information is completely free of error. $20.0 \%$ of respondents mention that accounting information generated by the commercial banks is partially free of error; $19.5 \%$ of respondents are undecided, and $7.3 \%$ of respondents believe that information is not free from error at all. The table represents that the commercial banks of Bangladesh decently maintain the quality of financial reporting in terms of free-from-error of accounting information. To identify any notable difference among the notions of the respondents regarding the accuracy of accounting information, produced by the AIS of the selected commercial banks, the following alternative hypothesis is drawn:
$\mathrm{H}_{2}$ : There is a notable difference in the notions of the respondent groups about the accuracy of accounting information generated by AIS of commercial banks in Bangladesh

To prove the existence of any significant variation among the opinions of the respondents regarding the free-fromerror quality of accounting information, produced by Accounting Information Systems of the selected commercial banks, Pearson Chi-square test $\left(\chi^{2}\right)$ using SPSS -22 was applied. The value of Pearson Chi-square test $(\chi 2)$ is $9.14(\mathrm{~N}=205, \mathrm{DF}=16, \mathrm{SD}=1.19$ and mode $=4)$ which is significant at .907 levels $(\mathrm{P}>0.1)$. Therefore, the hypothesis is unjustified, which means that there is no notable variation (homogeneity) of opinion among the respondents regarding the free-from-error quality of accounting information produced by Accounting Information Systems of the selected commercial banks in Bangladesh.

\section{Conclusions ANd ReCOMmendations}

Qualitative accounting information becomes a valuable source of timely and objective terms with which it is possible to a successful outcome. Commercial banks of Bangladesh have rapidly produced accounting information, and there is a similarity of opinion among the respondents regarding the timeliness of accounting information produced by AIS. The commercial banks of Bangladesh properly maintain the quality of financial reporting in terms of accuracy, and there is no significant variation (homogeneity) of opinion among the 
respondents regarding the quality of accounting information. Through interviews with stakeholders, it is identified that erratic power supply, inferior communication infrastructures, inadequate local input in the hardware and software chain, the accidental entry of poor data by the employees, virus infection in the program, unauthorized access to the data and system, unauthorized copying, printing and distributing of data or information, etc. are the mentionable problems of AIS practices in commercial banks of Bangladesh. To minimize such problems, the following recommendations emerge:

- The Government should take steps in the provision of infrastructural facilities such as power and communication network to enhance efficiency and make supply availabilities of local input in the hardware and software chain, which may increase the qualities of AIS in the banking sector of Bangladesh.

- $\quad$ Banks should keep an arrangement of backup data systems; install an anti-virus utility program that can reduce the risks and threats posed by the accidental data destruction by employees or virus infection.

- $\quad$ Banks should increase more safety for protecting data hacking, error, and misuse of data and should recruit technically sound employees in this regard.

- Concern authorities of banks should always monitor the fishy official who may carry out unauthorized copying, printing, and distributing of data or information contained in an annual report.

The study has focused on one avenue of banking disclosure, namely, annual reports, and has considered only the issue of quality in two areas, termed as timeliness value and free-from-error quality. The effect of the quality of information is a broad and challenging area. Thus, further research is necessary on other avenues of disclosure, including quarterly and interim reports, bank circulars, financial press releases, prospectuses, monthly bulletin, and pamphlets to investigate the extent of other qualities, such as feedback value, credible value, clarity value, etc.

\section{REFERENCES}

Abdelkarim, N., Shahin, Y.A., and Arquawi. B.M. (2009). Investor Perception of Information Disclosed in Financial Reports of Palestine Securities Exchange Listed Companies, Accounting \& Taxation, vol. 1, issue 1, 45-61
Aljifri, K. (2008). Annual report disclosure in a developing country: The case of the United Arab Emirates (UAE). Advances in Accounting, 24, 93-100.

Bangladesh Bank. (2020). Bangladesh Bank's annual report 201819, Financial Inclusion Department, Bangladesh Bank, Dhaka, Bangladesh, P-3.

Bukenya, M. (2014). Quality of accounting information and financial performance of Uganda's public sector. American Journal of Research Communication, 2 (5), 183-203.

Bushman, R. M., \& Smith, A. I. (2004). Financial accounting information and corporate governance. Journal of Accounting E Economics, 32 (3), 237-333.

Hasan, M. S., Abdullah, S. N. B., \& Hossain, S. Z. (2014). Qualitative characteristics of financial reporting: An evaluation of users' perception in Bangladesh. The Pakistan Accountant, January-March, 23-31.

Kaplan, D., Krishnan, R., Padman, R. \& Peters, J. (1998). Assessing Data Quality in Accounting Information Systems, Communications of the ACM 41 (2), 72-78.

Kieso, E., \& Weygandt, J. (2006). Intermediate accounting. 12th Edition, John Wiley \& Sons Inc., U.S.A, 36-39.

Naser, K., Nuseibeh, R., \& Al-Hussaini, A. (2003). Users' perceptions of various aspects of Kuwaiti corporate reporting. Managerial Auditing Journal, 18 (6/7), 599-617.

Neogy, T. K. (2014). Qualitative characteristics of accounting information: A study on mobile telecommunication companies in Bangladesh. ASA University Review, 8 (1), 6981.

Nicolaou, A. I. (2000). A contingency model of perceived effectiveness in accounting information systems: Organizational coordination and control effects. International Journal of Accounting Information Systems, 1(2), 91-105.

Obaidat A.N. (2007). Accounting Information Qualitative Characteristics Gap: Evidence from Jordan. International Management Review, 3(2), 26-32.

Redman, T. C. (1992). Data quality: management and technology. Bantam Books, Inc. New York.

Salehi, M., \& Rostami, V. (2011). A Necessity for reengineering the qualitative characteristics of financial reporting arrangement in the reduction of information asymmetry: An evidence of Iran. African Journal of Business Management 5 (8), 3274-3288.

Stoner, J., Freeman, E., \& Gilbert, D. J. (1995). Management, $6^{\text {th }}$ edition, Prentice-Hall International Inc. England.

Sumon, D., \& Shilpi, D. (2008). Accounting information system of the financial institutions in Bangladesh: An evaluation. The Bangladesh Accountant, October-December, 1-15.

$--0-$

\section{How to cite this article:}

Ahamed, M. J. (2020). Timeliness Value and Free-from-error Quality of Accounting Information: A Study on Commercial Banks. Asian Business Review, 10(2), 137-142. https://doi.org/10.18034/abr.v10i2.479 